2002

The Asbestos Case and Dispute Settlement in the World Trade Organization: The Uneasy Relationship Between Panels and the Appellate Body

Sydney M. Cone III.

New York Law School, sydney.cone@nyls.edu

Follow this and additional works at: http://digitalcommons.nyls.edu/fac_articles_chapters

Part of the Environmental Law Commons

Recommended Citation

23 Mich. J. Int'l L. 103 (2001-2002)

This Article is brought to you for free and open access by the Faculty Scholarship at DigitalCommons@NYLS. It has been accepted for inclusion in Articles \& Chapters by an authorized administrator of DigitalCommons@NYLS. 


\title{
THE ASBESTOS CASE AND DISPUTE SETTLEMENT IN THE WORLD TRADE ORGANIZATION: THE UNEASY RELATIONSHIP BETWEEN PANELS AND THE APPELLATE BODY
}

\author{
Sydney M. Cone, $I I^{*}$
}

INTRODUCTION 103

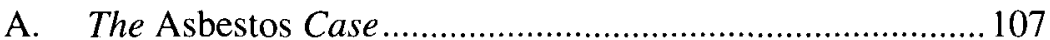

B. Certain Issues Raised by the Asbestos Case........................110

1. Article III:4_-"Like Products"....................................... 110

2. Burden of Proof ...........................................................119

3. Article XI-Non-Tariff Barrier ......................................121

4. Article XX(b)-Human Life or Health .........................121

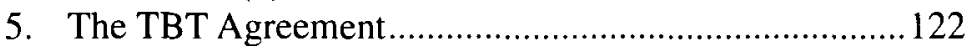

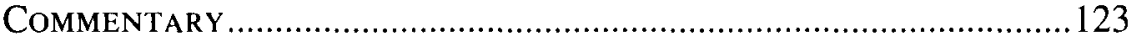

1. "Like Products"............................................................. 123

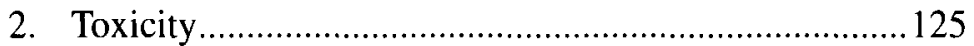

3. Evidence as to "Likeness"............................................126

4. "Aim and Effects" Test ............................................... 128

5. Non-Tariff Barrier ........................................................ 129

6. "Measures Necessary to Protect

Human Life or Health"............................................... 130

7. The TBT Agreement ...................................................136

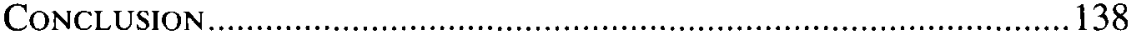

\section{INTRODUCTION}

This article deals with the working-level dispute-settlement apparatus of the World Trade Organization ("WTO").' In particular, it discusses

* C.V. Starr Professor of Law, New York Law School; Of Counsel, Cleary, Gottlieb, Steen \& Hamilton

1. Following the Uruguay Round of trade negotiations, the WTO was created as from January 1, 1995 by the Final Act Embodying the Results of the Uruguay Round of Multilateral Trade Negotiations, Apr. 15, 1994, LEGAL InSTRUMENTS - RESUlts of THE URUGUAY RouND vol. 1 (1994), 33 I.L.M. 1143 (1994) and the agreements annexed thereto and incorporated therein, three of which are particularly relevant to this article: the General Agreement on Tariffs and Trade 1994, Apr. 15, 1994, Marrakesh Agreement Establishing the World Trade Organization [hereinafter WTO Agreement], Annex IA, LEGAL InSTRUMENTS-REsulTs of THE URUGUAY Round vol. 1 (1994), 33 I.L.M. 1154 (1994) [hereinafter GATT 1994]; the Agreement on Technical Barriers to Trade, Apr. 15, 1994, WTO Agreement, Annex 1A, LEGAL INSTRUMENTS-RESUlts of THE URUGUAY Round vol. 27 (1994) [hereinafter TBT Agreement]; and the Understanding on Rules and Procedures Governing the Settlement of Disputes, Apr. 15, 1994, WTO Agreement, Annex 2, Legal Instruments-Results of THE UruguaY 
the work of the Appellate Body and, functioning below it, panels established by the WTO to conduct proceedings in individual cases. ${ }^{2}$ It focuses on the relationship between the Appellate Body and panels, and on the responsibilities of the Appellate Body in the context of that relationship.

This article's principal point of departure in examining that relationship is the WTO case known as the Asbestos case, in which a WTO panel issued a report in November $2000,{ }^{3}$ and the Appellate Body issued a report in March 2001. The case attracted considerable attention because it took place against a background of criticism by some commentators of the way in which the WTO has balanced the policy of fostering multilateral trade against non-trade policies involving, for example, the environment, health, and the treatment of workers. ${ }^{5}$ These policy issues are not the main focus of this article, however, in part because it concentrates on the relationship between the Appellate Body and WTO panels as such, and in part because, in any event, the mandate and resources of the WTO limit its authority outside the area of multilateral trade.

A brief introductory summary seems in order concerning the Appellate Body and WTO panels. Under the old GATT, ${ }^{6}$ the predecessor to the WTO, dispute settlement was handled by panels, and their creation and reports were subject to confirmation by all of the GATT member coun-

Round vol. 31 (1994), 33 I.L.M. 1226 (1994) [hereinafter Dispute Settlement Understanding or DSU]. As of Jan. 1, 2002, the WTO had 144 members, and some 30 additional countries were seeking membership.

2. See DSU. See also Gabrielle Marceau \& Peter Morrison, World Trade Organization, The Wto Dispute Settlement Procedures: a Collection of legal Texts, WTO/OMC/1995-03 (1995); David Palmeter \& Petros C. Mavroidis, Dispute Settlement in the World Trade Organization: Practice and Procedure (1999); James Cameron \& Kevin R. Gray, Principles of International Law in the WTO Dispute Settlement Body, 50 In''L \& ComP. L.Q. 248 (2001). Panels are appointed pursuant to Articles 6 and 8 of the DSU. The Appellate Body has seven members appointed by the members of the WTO acting for the Dispute Settlement Body pursuant to Article 17.

3. Rapport du Groupe spécial, Communautés Européennes-mesures affectant l'amiante et les produits en contenant, WT/DS135/R (Sept. 18, 2000), http://www.wto.org [hereinafter Asbestos Panel report].

4. Report of the Appellate Body, European Communities-Measures Affecting Asbestos and Asbestos-Containing Products, WT/DS135/AB/R (Mar. 12, 2001), http://www.wto.org [hereinafter Appellate Body Asbestos report]. The seven-member Appellate Body acted in this case through a three-member Division composed of Messrs. Feliciano, Bacchus, and Ehlermann (the "AB Division").

5. See, e.g., the commentaries collected in Environment, Human Rights and INTERnational Trade (Francesco Francioni ed., 2001); Jenny Bates \& Greg Principato, Progressive Policy Institute, A Third Way on Trade and Globalization (July 18, 2000), at http://www.ppionline.org/ndol/print.cfm?contentid=1499; Steve Charnovitz, Progressive Policy Institute, Addressing Environmental and Labor Issues in the World Trade Organization (Nov. 1, 1999), at http://www.ppionline.org/ndol/print .cfm?contentid=649.

6. General Agreement on Tariffs and Trade, Oct. 30, 1947, 61 Stat. A-11, T.I.A.S. 1700, 55 U.N.T.S. 194 [hereinafter GATT 1947]. 
tries, with the result that on occasion panel proceedings were blocked or panel reports failed to come into effect. ${ }^{7}$ When the WTO came into being in 1995, the old GATT procedures were changed in several significant ways, of which two will be mentioned.

First, the Appellate Body was added, and countries that bring disputes before WTO panels have been given the right to appeal to the Appellate Body on issues of law or legal interpretations covered by or expressed in panel reports. Although the relevant written procedures seem to assume that WTO dispute settlement will be primarily the work of panels, with occasional resort to the Appellate Body on points of law, in practice the Appellate Body has become deeply involved in the handling of many disputes, and in a number of instances has issued reports that "complete the analysis" of, or otherwise rework in some detail, reports issued by panels. ${ }^{8}$

Second, there is no effective appeal from a report issued by the Appellate Body. It has no power of remand, and thus it cannot rule on a point of law in a case and then send the case back to a panel for further proceedings. More importantly, a report by the Appellate Body automatically comes into effect unless it is rejected by a unanimous vote of the WTO member-countries (sitting as the Dispute Settlement Body). Since at least the country benefiting from an Appellate Body report can be expected to vote in favor of the report, the practical result is that every report by the Appellate Body automatically comes into effect and is not subject to further review.

The Appellate Body is thus vested with considerable power, especially in the context of its relationship with individual panels whose reports it receives on appeal. If, in the opinion of the Appellate Body, a panel has committed error on a point of law in a particular case, the case

7. See Palmeter \& Mavroidis, supra note 2, at 1-18.

8. Pursuant to Article 3(1) of the DSU, the member countries of the WTO "affirm their adherence to the principles for the management of disputes heretofore applied" under GATT 1947, which refers in large part to the use of panels before the creation of the Appellate Body in the WTO. Eleven articles of the DSU (Articles 6 through 16) and a 12-section appendix thereto (Appendix 3) are devoted to panels. One article (Article 17) is devoted to the Appellate Body. The next two articles (Articles 18 and 19) are common to communications with and recommendations by both panels and the Appellate Body. On the development of the technique whereby the Appellate Body "completes the analysis" of a panel, see Sydney M. Cone III, The Appellate Body, the Protection of Sea Turtles, and the Technique of "Completing the Analysis," J. WORLD TRADE, April 1999, at 51, 56-61 (1999) [hereinafter Completing the Analysis). See also Cone, The Appellate Body and Harrowsmith Country Life, J. WorLD TRADE, April 1998, at 103, 113-15 [hereinafter Harrowsmith].

9. DSU Art. 2.4, 20. See Palmeter \& Mavroidis, supra note 2, at 61-62, 153-60; Completing the Analysis, supra note 8, at 59. Between the establishment of the WTO in 1995 and September 2001 , over 225 complaints were filed with the WTO, and over 50 reports by panels or the Appellate Body were adopted pursuant to the DSU. 
will not go back to the panel for further proceedings. If the Appellate Body rejects a panel's analysis of facts and law and proceeds to "complete the analysis" in a different manner from that employed by the panel, the analysis thus completed is not, as a practical matter, subject to review by anyone, and there is no opportunity for a further weighing of the work of the panel as against that of the Appellate Body. This means that, in any given case, the Appellate Body, as a practical matter, has ultimate and definitive authority to determine the proper scope and content of changes to, or rejections of, a panel's analysis carried out by the Appellate Body in order to "complete the analysis" of the panel or otherwise to dispose of the panel's report."

The considerable power of the Appellate Body just described means that it is in a position to act as the judicial suzerain of the WTO in individual cases-a position having important implications for the jurisprudence and the judicial administration of the WTO. It is these implications which provide the focus of this article. The Appellate Body, in the area of formulating WTO jurisprudence, develops the fundamental framework for decisionmaking by future panels in future cases. More generally, the Appellate Body is uniquely situated to provide administrative leadership that, properly exercised, will give coherence and effectiveness to panels and the Appellate Body acting as the judiciary of the WTO. It seems appropriate to consider whether, in these areas, the relationship between the Appellate Body and panels might be the subject of constructive reconsideration.

Reconsideration of the manner in which the Appellate Body disposes of the work of various panels in various cases raises the following types of questions. Are the Appellate Body and panels acting in concert in a shared judicial endeavor? Is their relationship informed by the common goals of handling cases efficiently, achieving judicial economy, and minimizing disharmony in the development of WTO jurisprudence? Is adequate attention given to the impact of individual decisions on the disposition of future cases? Where on a potential spectrum should panel reports be located between, for example, being considered as the workproduct of clerks, to be marked up or discarded without inhibition, and being treated as potential sources of substantive value and as integral to a single procedural continuum?

The concerns raised by these questions seem to be illustrated in an instructive manner by the Asbestos case. It was not a run-of-the-mill trade case, but one that required rulings in several key areas of the law governing multilateral trade. Because the case was being followed by constituencies both within and outside the WTO-constituencies con-

10. See Completing the Analysis, supra note 8, at 60-61. 
cerned with the promotion of multilateral trade by the WTO, and constituencies concerned that competing, non-trade policy objectives do not receive adequate attention within the $\mathrm{WTO}^{\prime \prime}$ - the case tested the capacity of the WTO's working-level dispute-settlement apparatus to reach decisions in a disciplined manner having due regard for the long-term, judicious development of WTO case law. Thus, in the context of the Asbestos case, this article will first outline the case, will next set out the issues in the case of relevance both to the substance of the case and the questions mentioned above, and will then proceed to analyze those issues.

\section{A. The Asbestos Case}

The case was brought by Canada against the European Union (the "EU") acting on behalf of France. ${ }^{12}$ Canada challenged a French decree that came into effect in January 1997 and that, in substantial part, banned the importation of products containing chrysotile asbestos. ${ }^{13}$ Theretofore, the leading exporter of those products had been Canada and, more exactly, Québec. ${ }^{14}$ Their exportation was of economic importance to Québec, and of political importance to Canada in light of relations between French- and English-speaking Canada. ${ }^{15}$ The prohibitions in the French decree were grounded in the carcinogenic characteristics of

11. Examples of non-trade-group interest in, and comments on, the Asbestos case are found in Daniel Pruzin, WTO Delays Releasing Decision in Complaint by Canada Against France's Ban on Asbestos, 17 Int'l Trade Rep. (BNA), No. 11, at 433 (2000); Daniel Pruzin \& Peter Menyasz, Environment: Environmental Groups Criticize WTO Ruling on Asbestos Ban, 17 Int'l Trade Rep. (BNA), No. 37, at 1432 (Sept. 21, 2000); Daniel Pruzin \& Peter Menyasz, WTO Appellate Body Upholds French Ban on Asbestos Imports, 18 Int'l Trade Rep. (BNA), No. 11, at 426 (Mar. 15, 2001); Michael M. Weinstein, Greens and Globalization: Declaring Defeat in the Face of Victory, N.Y. Times, Apr. 22, 2001, $\$ 4$ (Week in Review), at 18; Foundation for International Environmental Law and Development, on its behalf and on behalf of Ban Asbestos (International and Virtual) Network, Greenpeace International, International Ban Asbestos Secretariat, World Wide Fund for Nature, International, Letter and Joint Amicus Brief in European Communities-Asbestos and Asbestos-Containing Products, Feb. 6, 2001, available at http://www.field.org.uk/papers/pdf/asbestosamicus.pdf; Danielle Knight, Inter Press Service, Trade-Health: WTO Ruling Reveals Toxic Logic, Warn Groups (Sept. 19, 2000), available at http:/www.oneworld.org/ips2/sept00/16_19_062.html [hereinafter, collectively, NGO Commentaries].

12. The European Communities had joined the WTO, and the European Communities (in the singular) was the party against which Canada brought its complaint. This article uses the more familiar contemporary appellation, European Union or EU, rather than European Communities or $\mathrm{EC}$.

13. Decree No. 96-1133 of Dec. 24, 1996, J.O., Dec. 26, 1996, p. 19126; JCP 1997, III, 68259 [hereinafter French decree].

14. Asbestos Panel report, supra note 3, \1 3.20.

15. See Bill Schiller, WTO Rejects Canada's Case on Asbestos, Toronto Star, Sept. 19, 2000 , at E3. 
chrysotile asbestos. ${ }^{16}$ These prohibitions applied to asbestos products of domestic and foreign origin and did not single out products originating in Canada (or Québec). ${ }^{17}$

Among the issues raised by the case were questions concerning the national treatment of imported products, non-tariff barriers to imported products, the protection of public health, and technical barriers to trade. ${ }^{18}$ The first three arose under a WTO agreement known as GATT 1994, the fourth under the WTO Agreement on Technical Barriers to Trade (the "TBT Agreement"). The issue of national treatment is governed by paragraph 4 of Article III of GATT 1994 ("Article III:4"). The issue of nontariff barriers is governed by Article XI of GATT 1994 ("Article XI"). Public health is expressly mentioned in GATT 1994's Article XX, entitled "General Exceptions;" paragraph (b) of Article XX ("Article $\mathrm{XX}(\mathrm{b})$ ") relates to "measures" "necessary to protect human, animal or plant life or health."

In general form, the case followed a familiar pattern in disputes brought before panels under the old GATT and, in recent years, pursuant to the WTO dispute-settlement procedures. Canada, the complaining party, alleged (among other things) violations of Article III:4, Article XI, and the TBT Agreement. France (meaning the EU acting on behalf of France), the defending party, responded with both denials and a justification; that is, France both offered reasoned denials of the allegations, and additionally (as regards the alleged GATT 1994 violations) justified its decree as falling under one of the General Exceptions as set out in Article $\mathrm{XX}(\mathrm{b}){ }^{20}$

The WTO panel that considered the Asbestos case found a violation of Article III:4, therefore found it unnecessary to consider Article XI, and then proceeded to consider Article $\mathrm{XX}(\mathrm{b})$. It ruled that, notwithstanding the violation of Article III:4, the French decree was authorized by Article XX(b). ${ }^{21}$ In other words, Canada lost, and France won on the ground that the French decree was a measure necessary to protect human

16. Information concerning the danger to health posed by chrysotile asbestos is found in the Asbestos Panel report, supra note 3, particularly at $\mathbb{1} 5$ and in the Addendum thereto, WT/DS135/R/Add.1, http://www.wto.org.

17. See French decree, supra note 13; Asbestos Panel report, supra note 3, 178.224.

18. In addition to the claims under Articles III:4 and XI (and the related arguments under Article XX(b)) and the claim under the TBT Agreement, Canada made a claim under Article XXIII (1)(b) of GATT 1994 to the effect that, even if the French decree did not constitute a violation of GATT 1994, it constituted a non-violation nullification or impairment of Canada's legitimate trade expectations. This claim was viewed as meritorious by neither the panel nor the Appellate Body, and in the interest of brevity is not examined in this article. Asbestos Panel report, supra note 3, \ 8.304; Appellate Body Asbestos report, supra note 4, \$191.

19. GATT 1994 Art. XX(b).

20. See Asbestos Panel report, supra note 3, पा 8.3-.8.

21. See id. पा $8.144,8.159,8.241$. 
life or health from the carcinogenic threat of chrysotile asbestos products. As for the TBT Agreement, the panel found it inapplicable in the present case. ${ }^{22}$ On its face, then, not only did the case follow a familiar pattern of complaint, denials, and justification found in GATT/WTO case law, but also the panel's disposition of the case was consonant with that familiar pattern. In disposing of the case, the panel unequivocally permitted France to justify an exclusion of imports on grounds of public health.

Even so, advocates of environmental and public-health policies objected to the panel's finding that the French prohibition of imports violated Article III:4, and to a procedure that seemingly compelled France to justify that prohibition under Article XX(b) - a procedure, it was claimed, that put an undue burden on the party seeking to protect public health from a carcinogenic product. ${ }^{23}$ These reactions to the panel report raised questions as to the interpretation of Article III:4, and as to the proper burden of proof allocable to parties in WTO disputes.

On appeal, the Appellate Body reversed the panel's finding of a violation of Article III: $4,{ }^{24}$ thus making academic the panel's finding that the violation was justified under Article $\mathrm{XX}(\mathrm{b})$. Nevertheless, the Appellate Body provided its own analysis of Article XX(b), concluding (as had the panel) that, under Article XX(b), the French prohibition on imports was justified. ${ }^{25}$ It is significant that under the approach taken by the Appellate Body, the justification was academic, because the Appellate Body had decided that there was no Article III:4 violation in need of justification. Like the panel, the Appellate Body declined to rule on Canada's claim under Article XI, ${ }^{26}$ which meant that neither the panel nor the Appellate Body considered whether the French decree imposed a non-tariff barrier inconsistent with Article XI as claimed by Canada. In the case of the Appellate Body, Canada's claim of an Article XI violation was no longer clearly redundant, because the Appellate Body, unlike the panel, had found that there was no violation of Article III:4. While the Appellate Body did not say so, its views on Article XX(b) presumably meant that, had it been found that the French decree constituted a violation of Article $X I$, the violation would have been justified on public-health grounds under Article XX(b). As for the TBT Agreement, the Appellate Body reversed the panel's finding that that Agreement was not relevant to the

22. See id. \1 8.73 .

23. See NGO Commentaries, supra note 11.

24. Appellate Body Asbestos report, supra note 4, II 148.

25. Id. भाषा 155-75.

26. The Appellate Body report mentions Canada's Article XI claim, but does not discuss it. Id. III 3,5 . 
present case, but declined to rule one way or the other on how the TBT Agreement should be applied to the case. ${ }^{27}$

\section{B. Certain Issues Raised by the Asbestos Case}

In the following description, more detailed attention will be given to the issues raised by the Asbestos case in respect of (1) Article III:4, (2) Article XI, (3) Article XX(b), and (4) the TBT Agreement. The following description is based on the original panel report (which, involving as it does a dispute between Québec and France, is in French), and on the report of the Appellate Body (which is in English).

\section{Article III:4__"Like Products"}

For present purposes, the relevant provisions in Article III of GATT 1994 are paragraphs 1, 2, and 4-“Article III: 1," "Article III:2," and "Article III:4" - and a supplementary provision found in Annex I to GATT 1994 relating to Article III:2 ("Ad Article III:2"). Article III:1, which is said to inform all of Article III, states that internal taxes and other internal regulations "should not be applied to imported or domestic products so as to afford protection to domestic production."28

Article III:2, which deals with internal taxes, has three parts. The first sentence states that imported products shall not be subject to internal taxes in excess of those applied to "like domestic products." The second sentence, which is drafted as an addition to the first, incorporates Article III: 1, thereby forbidding internal taxes that "afford protection to domestic production." Ad Article III: 2 clarifies the difference between the first and second sentences, and states that a tax conforming to the requirements of the first sentence is not consistent with the second sentence when there is a taxed product and "a directly competitive or substitutable product which [is] not similarly taxed." Article III:2's two sentences thus contain two prohibitions. One forbids taxes on imports in excess of taxes on "like domestic products." The other forbids taxes on imports when "directly competitive or substitutable" domestic products are not similarly taxed. These two sentences have been construed to mean that "like products" constitute a narrower category than "directly competitive or substitutable products"; that any tax differential whatever between "like products" is suspect; but that a de minimis tax differential would not constitute a violation of the second sentence. Put differently,

27. Id. II $59-83$.

28. The view that this principle in Article III: 1 informs all of Article III is found under "G. Article III:I" in the Report of the Appellate Body, Japan-Taxes on Alcoholic Beverages, WT/DS8, 10, 11/AB/R (Oct. 4, 1996), at 17-18, http://www.wto.org [hereinafter Alcoholic Beverages case]. 
any tax discrimination between "like products" may violate the first sentence, but "like products" for this purpose is a relatively narrow concept. On the other hand, while minimal discrimination may not violate the second sentence, "directly competitive or substitutable products" is a relatively broad concept. ${ }^{29}$

The Asbestos case involved a claim by Canada not under Article III:2 (just discussed) but under Article III:4. This provision requires that imported products

shall be accorded treatment no less favorable than that accorded to like products of national origin in respect of all laws, regulations and requirements affecting their internal sale, offering for sale, purchase, transportation, distribution or use..$^{30}$

As can be seen, Article III:4 uses the term "like products" that has already appeared in Article III:2, but uses only that term and (in contrast to Article III:2) does not refer to the additional concept of "directly competitive or substitutable products." In the Asbestos case, as in other cases, the use of "like products" in one way in Article III:2 and in another way in Article III:4 can raise questions of interpretation. These questions are examined further on in this discussion.

Canada's "like products" claim under the Article III:4 provision quoted above was to the effect that, while the French decree forbade the sale of chrysotile asbestos products in France, it did not forbid the sale in France of other, non-asbestos products which were "like" the asbestos products. These other products, briefly, were derived not from chrysotile asbestos fibers but from polyvinyl alcohol fibers, cellulose fibers, or glass fibers. These non-asbestos-based products will be referred to as "substitute products." The Canadian claim, then, was that asbestos-based products and substitute products were "like products" but that, pursuant to the French decree and in violation of Article III:4, asbestos-based products were accorded treatment less favorable than that accorded to substitute products. ${ }^{31}$

The panel found that asbestos-based and substitute products were "like products;" that, pursuant to the French decree, the former had been accorded less favorable treatment than the latter; and that the French decree therefore violated Article III:4. To determine whether the two categories of product were "like" for purposes of Article III:4, the panel relied to a substantial extent on a report issued by the Appellate Body in

29. An extensive discussion of these concepts is found under " $H$. Article III:2" in the Alcoholic Beverages case. Id. at 18-31.

30. GATT 1994 Art. III:4.

31. For the Canadian claim under Article III:4, see the Asbestos Panel report, supra note 3, $1198.101-.158$. 
September 1996 in a case known as Japan-Alcoholic Beverages (the "Alcoholic Beverages case").

The Alcoholic Beverages case arose under Article III:2 (not III:4); it involved taxes imposed by Japan on imported and domestic alcoholic beverages. The level of taxation was higher for imported than for domestic beverages. The key issue was whether the imported and domestic beverages were "like products" within the meaning of the first sentence of Article III:2, or "directly competitive or substitutable products" within the meaning of the second sentence of Article III:2. Substantially all of the products in question were found to be either "like" or "directly competitive or substitutable," with the result that the tax regime was found to be in violation of Article III: $2 .^{33}$

In the Alcoholic Beverages case, the Appellate Body had affirmed the rejection by the panel in that case of an "aim and effects" test proposed by the United States and Japan to give meaning to the concept of "like products" in Article III. Under this test, had it been adopted, a violation of Article III:2 or Article III:4 would depend on whether measures discriminating between imported and domestic products had as their purpose and as their trade effects the protection of the domestic products against the imported products. ${ }^{34}$ Rather than adopt this approach, the Appellate Body had endorsed four criteria for determining whether products are "like products." These four criteria can be summarized as follows: (1) the physical properties of the products; (2) the extent to which the products are susceptible of serving the same or similar enduses; (3) the extent to which consumers perceive and treat the products as alternative means of performing particular functions in order to satisfy a particular want or demand; and (4) the international tariff classification of the products. ${ }^{35}$

The panel in the Asbestos case used these four criteria as a framework for analyzing the question of whether, under Article III:4, asbestos products and substitute products are "like products." ${ }^{36}$ The panel read Alcoholic Beverages as giving panels an element of discretion ("un élément de jugement discrétionnaire") in applying the four criteria. ${ }^{37}$ The Appellate Body, the panel said, had accorded flexibility to panels in examining the question of likeness ("dans leur examen du principe de

32. See id. TI 8.112-.114; Alcoholic Beverages case, supra note 28.

33. See Alcoholic Beverages case, supra note 28, at 31-32 ("I. Conclusions and Recommendations").

34. See Robert E. Hudec, GATT/WTO Constraints on National Regulation: Requiem for an "Aim and Effects" Test, 32 INT'L LaW. 619, 626-28 (1998).

35. See Appellate Body Asbestos report, supra note 4, Tा 101.

36. Asbestos Panel report, supra note 3, TTI 8.113-.150.

37. Id. II 8.114 . 
similarité"). ${ }^{38}$ The Asbestos panel decided that the four criteria were substantially interdependent, and that it was not appropriate to examine each of them in isolation from the others. ${ }^{39}$ In relying on Alcoholic Beverages, an Article III:2 case, the panel in effect merged the Article III:2 concepts of "like products" and "competitive or substitutable products," taken together, to arrive at a broad meaning of "like products" for purposes of Article III:4." The panel thus rejected an "extremely narrow" definition of "like products" for purposes of Article III:4, and said that, for products to be "like" under Article III:4, it suffices that, for a given usage, the properties of the products be the same to the point that one product can replace another. ("Il suffit que, dans une utilisation donnée, les propriétés soient les mêmes au point qu'un produit puisse remplacer l'autre.") ${ }^{41}$

The Asbestos panel thus emphasized the second of the four Alcoholic Beverages critieria: the extent to which products, claimed to be "like," are susceptible of serving the same or similar end-uses. The panel's treatment of the other three criteria was less detailed. Having analyzed the end-uses criterion as such, it analyzed the physicalproperties criterion to a large extent (but not exclusively) in terms of end-uses. The panel was of the view that consumer preferences were not a reliable criterion in the present case; and it attached little importance to the matter of tariff classification, which differed for fibers but not for certain fiber-based products. ${ }^{42}$

The EU (on behalf of France) had urged the panel to take the carcinogenic characteristics of chrysotile asbestos into account when determining "likeness" on the basis of the physical-properties criterion. The argument was that toxicity was one of the physical characteristics of asbestos products and substitute products that was relevant to an appreciation of their "likeness." The toxicity of asbestos products, the EU argued, renders them physically unlike substitute products. ("Un produit dangereux doit être considéré comme présentant une nature et une qualité différentes d'un produit non dangereux ou moins dangereux." $)^{43}$

38. Id. $\mathbb{1} 8.123$.

39. Id. I 8.115 .

40. In $i d$. I 8.124, the panel cited the common consideration of the products in Report of the Panel, Japan-Customs Duties, Taxes and Labeling Practices on Imported Wines and Alcoholic Beverages, Nov. 10, 1987, GATT B.I.S.D. (34th Supp.) at 116-17 (1987), irrespective of whether they had been found "like products" or "competitive or substitutable products" in Alcoholic Beverages, supra note 27 , at 32 , and referred to them as a group as "like products" ("produits similaires au sens de l'article III:2"), adding that that case supported the panel's approach under Article III:4 ("Nous estimons que ce rapport confirme notre approche ... dans le cadre de l'article III:4 ....").

41. Asbestos Panel report, supra note 3, $\$ 8.124$

42. See id. भापा 8.117-.150.

43. Id. 118.119 . 
The panel rejected the EU argument, however, and declined to take health considerations into account in determining "likeness" for purposes of Article III: $4 .^{44}$

The panel expressed three reasons for refusing to consider toxicity as relevant to physical properties in the context of "like products" under Article III:4. The panel observed that in no previous WTO case had relative toxicity been considered a relevant physical characteristic for the purpose of determining whether different products are "like products.", (Here, although the panel understandably did not make the point, it might be observed that in the Alcoholic Beverages case, where the Appellate Body endorsed the four criteria for judging "likeness" in a case involving toxic products, it was not claimed that different levels of taxation of imported and domestic alcoholic products might be legitimately tied to different levels of toxicity.)

In addition, the panel stated that, for the purpose of applying the physical-properties criterion under Article III:4, the point at which physical properties should be taken into account is that moment at which asbestos products and substitute products may be interchangeably put to the same end-use. ("C'est ce moment-là qui nous intéresse, celui où elles sont utilisées à la même fin.") ${ }^{46}$

Finally, the panel was of the view that the very structure of the relevant multilateral trade agreement, namely, GATT 1994, dictated that a matter of public health, here, the toxicity of asbestos products as compared to substitute products, be determined not in the context of Article III:4, but in the context of Article XX(b), which deals expressly with the subject of measures necessary to protect human health or life. The panel said that it was reasoning in terms of the efficient allocation of subjectmatter within the structure of GATT 1994 ("la raison vient à notre avis de l'économie du GATT de 1994"), pursuant to which, the panel observed, the substantive provisions relating to issues of public health are found in Article XX(b). ${ }^{47}$

On appeal, the Appellate Body rejected the panel's view that the relative consequences for public health of asbestos products and substitute products should not be taken into account in determining whether they are "like products" for purposes of Article III:4. To reach the conclusion that "likeness" or "unlikeness" can be determined under Article III:4 on the basis of relative toxicity, the Appellate Body had to deal with several issues, including: (a) whether such a determination improperly

\footnotetext{
44. Id. $9418.130-.132$.

45. Id. $\$ 8.129$.

46. Id. $\ 8.125$.

47. Id. $9 T 18.129-.132$.
} 
intrudes on the intended purpose for which Article $\mathrm{XX}(\mathrm{b})$ was included in GATT 1994; (b) the scope of "like products" in Article III:4; (c) the application to asbestos products and substitute products of the four criteria of "likeness" found in the Alcoholic Beverages case; and (d) the allocation of the burden of proof under Articles III:4 and XX(b).

\section{a. Respecting the Intended Purpose of Article XX(b)}

The Appellate Body said that Article III:4 should not be restricted "simply because Article XX(b) exists and may be available to justify measures inconsistent with Article III:4." According to the Appellate Body, the fact that using Article III:4 "implies a less frequent recourse to Article XX(b)" does not deprive the latter of its utility. Evidence relating to health risks, the Appellate Body said (in italics) is relevant under Article III:4 to "the competitive relationship in the marketplace" of allegedly "like" products, while the same evidence under Article XX(b) can be invoked to justify a "WTO-inconsistent measure on the grounds of human health., ${ }^{, 48}$

The Appellate Body thus reasoned that evidence relating to human health, when it bears on competitive relationships in the marketplace, can be considered under Article III:4 in making a determination as to "like products." In this manner, the Appellate Body rejected the reasoning of the panel to the effect that the very structure of GATT 1994 requires that measures adopted to protect human health should be evaluated solely under Article XX(b).

\section{b. "Like Products" in Article III:4}

In substance, although not in language, the Appellate Body adopted the panel's view of the scope of "like products" for purposes of Article III:4. The panel had simply drafted its report as though "like products" in Article III:4 equals the sum of "like products" and "directly competitive or substitutable products" in, respectively, the first and second sentences of Article III:2. To reach substantially the same result, the Appellate Body referred to its image in earlier cases comparing the term "like products" to an accordion which stretches or contracts in different places in GATT 1994; declined "to define the precise scope of the word 'like' in Article III:4"; yet reached two conclusions-one being that "like" is broader in Article III:4 than in the first sentence of Article III:2, the other (buttressed by three italicized words) being that "like" in Article III:4 is "not broader than the combined product scope of the two sentences of Article III:2,"49

48. Appellate Body Asbestos report, supra note 4, II 115.

49. Id. भाष 96-99. 


\section{c. Applying the Four Criteria of "Likeness"}

The key question for the Appellate Body in the Asbestos case was whether asbestos products and substitute products are "like products." The panel, applying the four criteria of "likeness" in the Alcoholic Beverages case, had answered the question in the affirmative. The Appellate Body, applying the same criteria, seemed inclined to answer the question in the negative, saying that the evidence presented to the panel "rather tends to suggest that these products [asbestos products and substitute products] are not 'like products' for the purposes of Article III:4 . . ."50 To go from affirmative to negative, the Appellate Body effectively rejected the flexible approach taken by the panel in assessing and applying the four criteria, and asserted that each of the four must be examined and applied separately. The four-step approach of the Appellate Body can be summarized, criterion by criterion, as follows.

\section{i. Physical Characteristics}

In the Asbestos case, the Appellate Body was following its custom of acting through a three-member Division of its membership (the "AB Division"). Two members said that toxicity should be subsumed under the criterion of physical characteristics. So doing, these two members of the $\mathrm{AB}$ Division were able to distinguish asbestos products from substitute products on the ground that carcinogenic risk to human health is a physical property relevant to judging the competitive "likeness" of the two categories of products. The third member of the AB Division-in a "concurring statement" (which, in form, stopped short of being a separate concurring opinion)-implied that carcinogenic risk, instead of being treated as a physical characteristic, should be viewed as a standalone, health-based fifth criterion for purposes of ruling on "likeness."

The two members of the AB Division who did not agree with the creation of a fifth, health-based criterion for "likeness" seemed to reason that, conceptually and contextually, Article III:4 deals exclusively with economic, competitive relationships, and is not a provision intended to govern the protection of human health. These two members of the $A B$ Division seemed to be saying that, given this construction of Article III:4, the Appellate Body is entitled to create criteria for judging "likeness" only on the basis of economic, competitive relationships. Apparently, therefore, two members of the AB Division, having adopted this view as to the availability of criteria for judging "likeness," were

50. Id. पा 141 .

51. The concurring statement is found in id. at III 149-54. Since the three members of the AB Division signed the Appellate Body report, it would have seemed logical for the concurring member to sign his statement and not leave his identity to guesswork. 
unwilling (in contrast to the concurring third member) to take the step (in the words of the third member, the "small and modest step",52) of creating a fifth, health-based criterion for "likeness." Instead, these two members reasoned that toxicity is relevant to "likeness" for purposes of, and within the confines of, the physical-characteristics criterion endorsed by Alcoholic Beverages. ${ }^{53}$

Thus, either by treating toxicity as a physical property and subsuming it under the physical-characteristics criterion for "likeness," or by implying a fifth, health-based criterion for judging "likeness," the $A B$ Division tentatively concluded that carcinogenic asbestos products and non-carcinogenic substitute products are not "like products." The AB Division had stated, however, that each of the four criteria of Alcoholic Beverages must be considered separately, and it therefore proceeded to examine the other three in the manner summarized below. ${ }^{54}$

\section{ii. End-Uses}

The Appellate Body was critical of the panel's examination of whether asbestos products and substitute products have overlapping enduses. The panel, the Appellate Body said, only found that "the end-uses ... are the same "for a small number' of applications," and failed to offer any "elaboration on their nature and character." The Appellate Body noted, moreover, that the record provided no evidence regarding enduses of asbestos and substitute products "which are not overlapping." The Appellate Body therefore declined to rule on the significance of the fact that asbestos and substitute products "share a small number of similar end-uses."

\section{iii. Consumer Preferences}

The Appellate Body was even more critical of the manner in which the panel examined, or failed to examine, the criterion of consumer preferences. The Appellate Body concluded that such an examination "is an indispensable-although not, on its own, sufficient-aspect of any determination that products are 'like' ...." In reaching this conclusion, the Appellate Body had this to say:

We do not wish to speculate on what the evidence regarding these consumers [manufacturers of products including chrysotile asbestos or PCG fibers] would have indicated; rather, we wish to

52. $1 d$. I 153.

53. On competitive relationships, see id. at $19999,115-18$.

54. See id. .II 109, 133.

55. Id. शाप 137-38.

56. $I d . ~ \llbracket 139$. 
highlight that consumers' tastes and habits regarding fibres, even in the case of commercial parties, such as manufacturers, are very likely to be shaped by the health risks associated with a product which is known to be highly carcinogenic. A manufacturer cannot, for instance, ignore the preferences of the ultimate consumer of its products. If the risks posed by a particular product are sufficiently great, the ultimate consumer may simply cease to buy that product. This would, undoubtedly, affect a manufacturer's decisions in the marketplace. Moreover, in the case of products posing risks to human health, we think it likely that manufacturers' decisions will be influenced by other factors, such as the potential civil liability that might flow from marketing products posing a health risk to the ultimate consumer, or the additional costs associated with safety procedures required to use such products in the manufacturing process. ${ }^{57}$

With respect to the five sentences just quoted, the Appellate Body cited no basis in the panel's report for its statements, and otherwise offered no footnotes or documentation for the last four sentences. The Appellate Body appended the following footnote at the end of the first sentence:

We recognize that consumers' reactions to products posing a risk to human health vary considerably depending on the product, and on the consumer. Some dangerous products, such as tobacco, are widely used, despite the known health risks. The influence known dangers have on consumers' tastes and habits is, therefore, unlikely to be uniform or entirely predictable. ${ }^{58}$

Further on in its report, the Appellate Body had this to say about consumer preferences:

We consider it likely that the presence of a known carcinogen in one of the products will have an influence on consumers' taste and habits regarding that product. It may be, for instance, that, although cement-based products containing chrysotile asbestos fibres are capable of performing the same functions as other cement-based products, consumers are, to a greater or lesser extent, not willing to use products containing chrysotile asbestos fibres because of the health risks associated with them. Yet, this is only speculation; the point is, there is no evidence. We are of the view that a determination on the "likeness" of the cement-

57. Id. 11122 (footnote omitted).

58. Id. 9122 n. 103. 
based products cannot be made, under Article III:4, in the absence of an examination of evidence on consumers' tastes and habits. And, in this case, no such evidence has been submitted. ${ }^{59}$

With respect to the five sentences just quoted, the Appellate Body offered no footnotes other than a footnote referring back to its own earlier comments on consumer preferences.

\section{iv. Tariff Classification}

In effect, the Appellate Body added little to the panel's discussion of the tariff-classification criterion. It noted the existence of different tariff classifications for asbestos fibers and substitute fibers, and also noted that the tariff classification is the same "for any given cement-based product" irrespective of whether the product contains asbestos fibers or substitute fibers. The Appellate Body declined to determine what importance should be attached to tariff classifications "[i]n the absence of a full analysis, by the Panel, of the other three criteria addressed . . ., other words, while the Appellate Body proceeded to "complete the analysis" offered by the panel for the first three criteria, it declined so to act as regards the fourth criterion.

\section{Burden of Proof}

The panel had briefly addressed the matter of comparative burden of proof under Article III:4 and under Article XX(b), and had concluded that it made no significant difference whether the EU had the burden of disputing "likeness" under Article III:4 on the basis of the threat that asbestos products pose for human health, or had the burden of showing that, under Article XX(b), France was entitled to prohibit the importation of asbestos on the basis of that same threat. "Certes, la charge de la preuve ne serait sans doute pas sensiblement modifiée dans la mesure où les [Communautés Européennes] auraient toujours à apporter la preuve de la dangerosité du produit, en application de l'adage probatio incumbit ejus que dixit." $)^{62}$

The Appellate Body did not directly address this statement by the panel that, irrespective of the rubric under which the EU's claim of a health threat ("dangerosité du produit") was judged, the burden of proving that claim would be on the EU (on "ejus que dixit"); nor did the Appellate Body otherwise compare the burden of proof for the EU under

59. Id. \145 (footnote omitted).

60. Id. $\mathbb{1} 146$.

61. Id. I 124.

62. Asbestos Panel report, supra note 3, I 8.130. Roughly translated, the adage says that the burden of proof is on the claimant. 
Article III:4 and under Article XX(b). That is, the Appellate Body did not directly comment on the panel's observation that the burden of proof would not be significantly changed ("sensiblement modifiée") as between showing "unlikeness" on grounds of a threat to human health (Article III:4), or justifying the prohibitions in the French decree on the same grounds (Article XX(b)).

Rather, the comments of the Appellate Body on burden of proof were substantially limited to the "very heavy burden ... placed on Canada" to prove "likeness" under Article III:4, once the carcinogenic nature of asbestos products is taken into account. In particular, the Appellate Body observed that, it being "clear" that the two categories of products (asbestos products and substitute products) "have very different [physical] properties ... because chrysotile is a known carcinogen, a very heavy burden is placed on Canada to show, under the second and third criteria [end-uses; consumer preferences], that [asbestos products and substitute products] are in ... a competitive relationship." ${ }^{63}$ This approach to burden of proof has the following elements. It relates to the burden of the complaining party (Canada) to prove "likeness" under Article III:4 by showing a "competitive relationship" between asbestos products and substitute products. It is premised on the carcinogenic nature of asbestos products and the non-carcinogenic nature of substitute products. The burden on the party seeking to show "likeness" is "very heavy" because that party must show, notwithstanding the carcinogenic feature of asbestos products, that those products have overlapping enduses with, and appeal to the same consumer preferences as, substitute products that are not known carcinogens.

This approach to burden of proof seems to be interrelated with the views of the Appellate Body on the criteria for showing "likeness." It seems to be to the effect that, because the carcinogenic nature of asbestos products makes them physically "unlike" substitute products, the complaining party has a "very heavy burden" to prove that, under the end-uses and consumer-preferences criteria, asbestos products are "like" substitute products. If this reading of the Appellate Body's treatment of burden of proof is correct, then the subject was dealt with only as to Canada's burden to show "likeness" in the context of the second and third criteria (end-uses; consumer preferences), and only after a presumption of "unlikeness" had been raised on the ground that the carcinogenic nature of asbestos products constitutes a physical property under the first criterion.

63. Appellate Body Asbestos report, supra note 4, 4118. 


\section{Article XI-Non-Tariff Barrier}

Before the panel, Canada had claimed that the French decree violated not only Article III:4 but also Article XI's prohibition against nontariff barriers. ${ }^{64}$ In response, the EU had argued that only Article III:4, to the exclusion of Article XI, was applicable to the French decree. The EU argument was to the effect that the decree was an internal French regulation applicable to both domestic and imported products, that it was not a measure covering only the importation of products, and that it therefore fell under Article III:4. According to the EU, under established GATT practice, if a measure applies to both domestic and imported products, it is governed by Article III:4. ${ }^{65}$ Canada, on the other hand, took the further position that, if the decree cannot be considered under both Article III:4 and Article XI, it should be evaluated as a quantitative restriction in violation of Article XI, since, considered overall, the essence of the decree is to erect a non-tariff barrier against imports. ("Considéré d'une manière globale, le Décret porte, de par sa substance et son caractère véritable, sur les importations.") ${ }^{66}$

This Article XI controversy was not resolved. The panel upon finding a violation of Article III:4 found it unnecessary to reach Article XI. The Appellate Body, reversing the panel as to Article III:4 and affirming as to Article XX(b), did not deal with Article XI.

\section{Article $X X(b)-H u m a n$ Life or Health}

Both the panel and the Appellate Body determined that the French decree was a measure necessary to protect human life or health and, as such, came under the ambit of Article XX(b). The panel relied on expert testimony relating to the deadly nature of, and measures necessary to protect the public from fatal diseases caused by, chrysotile asbestos. The panel report reviewed this testimony in some detail. ${ }^{67}$ In large part, the Appellate Body relied on the panel report in this connection, observed that the panel enjoyed considerable discretion in the evaluation of the testimony in question, and concluded that the panel had not abused its discretion. ${ }^{68}$ According to the Appellate Body:

64. Asbestos Panel report, supra note 3, 113.394.

65. Id. TI 3.395-.396. The EU was relying on language found in Ad Article Ill of GATT 1994.

66. Asbestos Panel report, supra note 3, पाTा 3.467-.468, 3.470.

67. The testimony and related text are extensive, covering almost 200 single-spaced pages in the panel report (entitled Consultation du groupe spécial avec des experts scientifiques), plus an Addendum, supra note 16, of over 200 single-spaced pages. See Asbestos Panel report, supra note 3, III 5.1-.659.

68. See Appellate Body Asbestos report, supra note 4, III 162-63. 
The Panel enjoyed a margin of discretion in assessing the value of the evidence, and the weight to be ascribed to that evidence. The Panel was entitled, in the exercise of its discretion, to determine that certain elements of evidence should be accorded more weight than other elements-that is the essence of the task of appreciating the evidence. ${ }^{69}$

In particular, the Appellate Body affirmed the panel's rejection of the Canadian argument based on the "controlled use" of asbestos products. Here, the panel had concluded that France, in formulating its decree, could reasonably conclude that "controlled use" was not a "reasonably available" measure for dealing with asbestos products.

\section{The TBT Agreement}

The TBT Agreement (dealing with technical barriers to trade) is one of the agreements that was prepared in connection with, and that came into effect upon, the creation of the WTO. One of its recitals indicates that it was drafted to "further the objectives of GATT 1994," and another of its recitals sets out language identical to language found in Article XX of GATT 1994 (relating, among other things, to measures necessary for the protection of human life or health). ${ }^{7}$

Canada argued that the French decree constituted a technical regulation incompatible with the TBT Agreement. ${ }^{72}$ The panel dismissed this argument on the ground that the relevant portion of the French decree was not a technical regulation but a general prohibition of asbestos products. $^{73}$ The Appellate Body, noting that another portion of the French decree contains exceptions to the general prohibition, reversed the panel on this point, and ruled that the French decree, taken as a whole, does constitute a technical regulation for purposes of the TBT Agreement. ${ }^{74}$ Having done this, however, the Appellate Body did not decide whether the French decree does or does not violate the TBT Agreement. ${ }^{75}$

The Appellate Body thus declined to rule on Canada's claim under the TBT Agreement. Its inaction in this regard seems to have had two bases. First, the panel had made no findings in respect of the Canadian claim. Second, according to the Appellate Body, the meaning of the "obligations" in the TBT Agreement, as well as in a predecessor agreement under the old GATT, had never been construed by any GATT or WTO

69. Id. $\$ 161$.

70. Id. III $173-75$.

71. TBT Agreement pmbl., second and sixth recitals, respectively.

72. See Asbestos Panel report, supra note 3, पाप 3.245-.249.

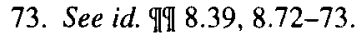

74. Appellate Body Asbestos report, supra note 4. IT 64-76.

75. Id. शाI 78-83. 
panel, or by the Appellate Body itself..$^{76}$ Leaving the Canadian claim in limbo thus appears to have been consistent with a tradition of not supplying interpretations of the "obligations" in the TBT Agreement.

\section{COMmentary}

There follows a commentary on the aspects of the Asbestos case set out above. Its focus is the relationship between the panel and the Appellate Body in the case itself and, more generally, in the context of WTO dispute settlement.

\section{1. "Like Products"}

As discussed above, the panel gave "like products" in Article III:4 the same scope given to both "like products" and "directly competitive and substitutable products" in the Appellate Body's report in the Alcoholic Beverages case, and took a flexible approach in applying the four criteria endorsed by that case for determining "likeness." So doing, the panel determined that asbestos products and substitute products are "like products" at the critical point when their properties are evaluated in terms of their end-uses. Also as discussed above, the Appellate Body provided an exegesis on the variable scope of "likeness," announced that each of the four criteria of the Alcoholic Beverages case must be applied separately, announced that toxicity is a physical property for purposes of applying the first of those criteria, declined (by two votes to one in the $\mathrm{AB}$ Division) to announce that toxicity is a separate, fifth criterion, observed that the panel had not provided sufficient information on the degree to which asbestos products and substitute products do and do not have overlapping end-uses, speculated on consumer preferences as between asbestos products and substitute products, and in the course of its analysis suggested that they are not "like products."

The Appellate Body seems to have hesitated between two different ways to deal with the issue of "like products." One apparent line of reasoning was that the toxicity of asbestos products affects their ability to compete economically with substitute products to the point that, given the competitive, economic framework of Article III:4, the two categories of product cannot be considered "like" for purposes of Article III:4." The other and quite different line of reasoning was that the panel report failed to supply sufficient evidence under the four criteria to support a finding that asbestos products and substitute products are "like"

76. Id. 1181

77. See id. $1 \mathbb{1} 99,113-16$. 
products. ${ }^{78}$ Formally, the Appellate Body can be said to have concluded that there was insufficient evidence to sustain the Canadian argument for "like products." Substantively, however, the Appellate Body's reasoning as to "likeness" seems to have rested squarely on the toxicity of asbestos products. ${ }^{80}$ This apparent ambiguity as to the underlying reason(s) for Appellate Body's conclusion-was it toxicity, or was it lack of evidence?-merits further analysis, because the panel should be able to understand, and future panels should be able to understand, why the Appellate Body came to the conclusion that it did as to "likeness."

Moreover, either of those reasons has important implications for WTO jurisprudence. Has the law of "likeness" been changed so that toxic products are "unlike" non-toxic products when toxicity is viewed as a physical characteristic in the context of the first of the Alcoholic Beverages criteria? Or, notwithstanding the view that toxicity is a firstcriterion physical characteristic, would the report of the Asbestos panel have found favor with the Appellate Body had the panel scrupulously set out the evidence of "likeness" in some detail separately for each of the four criteria? The Appellate Body's analysis is not particularly helpful in answering these questions. Its accordion imagery as to "likeness" was merely a step toward the strangely worded and unnecessary dictum that "like products" in Article III:4 is not a broader concept than the combined concepts of "like products" and "directly competitive or substitutable products" in Article III:2. ${ }^{81}$ (The dictum may also be inaccurate, given the breadth of Article III:4_"all laws, regulations and requirements"-compared to that of Article III:2_-“internal taxes.")

Here, a word about the four criteria seems in order. There are, for present purposes, but three, because neither the panel nor the Appellate Body attached any significance to the fourth criterion relating to tariff classification. Of the three, it would seem that toxicity considered only as a physical characteristic under the first criterion is insufficient to establish "unlikeness." Otherwise, why did the Appellate Body insist on separately examining the second and third criteria? In this connection, it would seem that it examined the second criterion, end-uses, to show the inadequacy of the record as to "likeness," but that its discussion of the third criterion, consumer preferences, was intended to buttress a conclusion based on toxicity.

78. See id. .11 $118,145,147$.

79. See id. I 192(c). (d).

80. See supra text accompanying notes 53,57 , and 59 .

81. See Appellate Body Asbestos Report, supra note 4, 111 88, 96, 99. 


\section{Toxicity}

As has been mentioned, the two prevailing members of the AB Division seemed to be of the opinion that toxicity can be considered under Article III: 4 only as it relates to competitive, economic relationships, and cannot be considered there as it relates to measures adopted to protect human life and health. Although the Appellate Body did not say so, this view does not seem so different from the view of the panel to the effect that the proper context for considering human life and health is not Article III:4 but Article XX(b). Restricting itself to viewing toxicity in terms of its effect on economic competition, the Appellate Body, in its discussion of the second criterion, speculated on how consumers choose between toxic asbestos products, and non-toxic substitute products. It did not attempt to substantiate this speculation. Indeed, the only footnote in support of the Appellate Body's speculation on consumer reactions to the dangers of asbestos pointed out that tobacco is widely known to be a dangerous product, and that, despite this, consumer reactions are neither uniform nor predictable. ${ }^{82}$

Much of the Appellate Body's second-criterion speculation seems questionable. The Appellate Body suggested that manufacturerconsumers would be deterred by a lack of a market for asbestos products, or by fear of civil liability, or by additional costs associated with safety procedures. One can question, however, whether the French decree would have been necessary or would have become the subject of dispute if there were no French market for asbestos products. In addition, one can as easily speculate that manufacturers using asbestos products would consider civil liability or safety procedures as costs of doing business, and would take these factors into account in pricing their own products. For better or worse, it is not inconceivable that there is a substantial market for asbestos products, notwithstanding their known carcinogenic properties.

Speculation either way misses a fundamental point, namely, that measures taken to protect human life and health are rarely adopted on the basis of consumer preferences. Rather, they are adopted on the basis of decisions by public authorities as to what is in the public interest. Consumers may prefer unfettered access to this or that product harmful to human health. Notwithstanding such a preference, public authorities, exercising their judgment as to what is in the public interest, step in and deny unfettered access by would-be consumers to certain harmful products. Tobacco (the only product mentioned in the Appellate Body's only relevant footnote on the point) is illustrative (indeed, the footnote on the 
unpredictability of consumer preferences is more on point than the speculative text to which it is attached). ${ }^{83}$ Laws regulating consumer access to tobacco are not promoted by would-be consumers of tobacco products; they are the work of persons concerned with human health. Even more telling examples exist of public-health measures that flout consumer preferences, relating to quite strict prohibitions involving products that are deemed to be more harmful than tobacco. ${ }^{84}$

This point is not unrelated to the view of the panel that the provision of GATT 1994 applicable to toxicity is Article XX(b), dealing with measures necessary to protect human life and health. Whatever the merit of the panel's views as to the structure of GATT 1994, the Appellate Body does seem to have taken itself rather far afield by attempting to deal with "likeness" through speculation that would correlate toxicity with consumer preferences. To the extent that the Appellate Body's conclusion as to "likeness" is based on its speculation as to consumer preferences, the basis for the conclusion is not convincing.

\section{Evidence as to "Likeness"}

As mentioned above, the Appellate Body states in its report that the panel failed to provide adequate evidence that asbestos products and substitute products are "like products." This evidentiary point was raised in particular as regards the second criterion, that is, the end-uses of the two categories of products. The panel, the Appellate Body said, contented itself with establishing the bare fact that the end-uses of the two categories are the same for "a small number" of applications, and did not attempt to evaluate the applications for which the two categories do and do not have overlapping end-uses. ${ }^{85}$ It is thus strongly implied that the

83. Information on the regulation of tobacco in the United States can be found on the website of the National Center for Chronic Disease Prevention and Health Promotion: Tobacco Information and Prevention Source, Selected Actions of the U.S. Government Regarding the Regulation of Tobacco Sales, Marketing, and Use, at http://www.cdc.gov/tobacco/ overview/regulate.htm; Tobacco Information and Prevention Source, State Laws on Tobacco Control-United States, 1998 (June 25, 1999), available at http://www.cdc.gov/tobacco/ research_data/legal_policy/mmwrss699.htm; Tobacco Information and Prevention Source, State Laws on Tobacco Control-United States, 1998: MMWR Highlights (June 25, 1999), available at http://www.cdc.gov/tobacco/research_data/legal_policy/mmwr699fs.htm.

84. See, e.g., Controlled Substances Act, 21 U.S.C. $\$ \$ 801-904$ (2000).

85. The panel actually said the following:

[M]ême si les utilisations finales des fibres de chrysotile d'une part et les fibres [competitives] d'autre part ne sont les mêmes que dans une faible partie de leurs applications respectives, il y a des circonstances où ces applications sont similaires. A ce moment leurs propriétés sont équivalents, sinon identiques. ... 
two categories cannot be found to be "like products" for the purpose of Article III:4 because the evidence adduced by the panel to show "likeness" was inadequate.

This evidentiary and procedural reasoning is rather different from a finding of "unlikeness" on grounds of toxicity in one category but not the other. It seems to require substantial evidence of overlapping enduses to support a conclusion that the two categories have been shown to be "like." When one reads the reports of the panel and the Appellate Body, including the presentations of Canada and the EU, as a whole, however, this evidentiary reasoning as to end-uses seems rather thin. The arguments of the parties and the French decree itself seem premised on the proposition that, were asbestos products freely admitted into France, they would be put to a great many end-uses, no small number of which would be highly competitive with the end-uses of substitute products. The record suggests that unrestricted access to asbestos products would reveal a variety of potential end-uses for those products. ${ }^{86}$ Moreover, it would seem that overlapping end-uses, actual and potential, can shift over time, depending on technology and market opportunity, and that, health considerations to one side, asbestos products would not be restricted in competing with substitute products. In short, the Appellate Body's extrapolation of the "small number" of overlapping end-uses into a major evidentiary flaw seems somewhat artificial.

The discussion of end-uses by the Appellate Body seems artificial because it sidesteps the question of whether asbestos products are commercially substitutable for relevant non-asbestos products; that is, whether, in the absence of health-based legal restrictions on the importation and use of asbestos products, they would be imported and used as substitutes for the non-asbestos products to which they are being

\footnotetext{
Nous avons déjà constaté ci-dessus que les propriétés respectives des fibres de chrysotile d'une part et des fibres [competitives] d'autre part permettaient certaines utilisations finales identiques ou du moins similaires... . [A] notre avis, le fait que toutes les utilisations finales de ces fibres ne soient pas similaires ne suffit pas à en faire des produits non similaires.
}

Asbestos Panel report, supra note 3, III 8.125, 8.136 (footnote omitted). It can be argued that the Appellate Body failed to do justice to this text indicating that the panel, on evaluating end-uses, concluded (a) that there were a sufficient number of overlapping end-uses to render asbestos products and substitute products "like," and (b) that the fact that all of the end-uses were not "like" did not operate to make the two categories of product "unlike."

86. Both Canada and the EU emphasized the large number of end-uses for asbestos products. Canada referred to " 3000 applications" and elaborated thereon. The EU commented on the many uses for asbestos and the extremely broad range of products containing asbestos that are put on the market ("[C]ompte tenu des multiples applications de l'amiante, l'éventail des produits mis sur le marché en contenant a été extrêmement large”). Id. \$11 3.21, 3.23. 
compared ${ }^{87}$ As a commercial matter, the question of overlapping enduses turns on product substitutability in the marketplace. The panel report clearly shows that both Canada and the EU considered the relevant non-asbestos products to be substitutable for asbestos products. ${ }^{88}$ Thus, the record in the Asbestos case clearly supports the proposition that the relevant non-asbestos products are substitutable for asbestos products. It would, therefore, seem indisputable that, on the basis of this record, the reverse proposition is true, namely, that asbestos products are substitutable for the relevant non-asbestos products. This being so, it is difficult to understand why the Appellate Body, in its discussion of enduses, sidestepped a record showing that asbestos products are actual or potential substitutes for the relevant non-asbestos products. The Appellate Body's treatment of the lack of evidence as to "likeness" seems to distort the second criterion on end-uses. Given the overall record in the Asbestos case, it seems clear that, but for laws based on their carcinogenic properties, asbestos products would occupy a substantial place in commerce and hence in multilateral trade. On the point of overlapping end-uses, it thus seems clear that, but for those laws, asbestos products would represent an important commercial standard by which other products would be measured for a not inconsiderable number of end-uses.

\section{4. "Aim and Effects" Test}

As mentioned above, ${ }^{89}$ in the Alcoholic Beverages case the Appellate Body had affirmed a panel's rejection of a proposed "aim and effects" test whereby "likeness" under Article III would turn on whether the aim and trade effects of a measure were protectionist of domestic products against imported products. It is interesting to note that, had this test been adopted and thus been available in the Asbestos case, the panel in that case might have disposed of the case under Article III:4, and might not have had to reach Article XX(b). Because the French decree did not discriminate against imported products in order to protect domestic products, it presumably would not have been found in violation of the "aim and effects" test and, for this reason, imported asbestos products might not have been found by the panel to be "like products" for purposes of Article III:4. Use of "aim and effects," had it been made

87. The non-asbestos products here relevant are derived from polyvinyl alcohol fibers, or cellulose fibers, or glass fibers, and are referred to herein as "substitute products." See supra text preceding note 31 .

88. For Canada, see, for example, Asbestos Panel report, supra note 3, 때 3.28, 3.45 (b). For the EU, see, for example, id. . $\{113.426,3.428$

89. See supra text accompanying note 34 . 
available by the Appellate Body, could have greatly facilitated the search for an Article III:4 rationale for disposing of Asbestos.

\section{Non-Tariff Barrier}

If the panel's evidentiary failure (as asserted by the Appellate Body) means that asbestos products and substitute products have no material overlapping end-uses, then it might well follow that (for purposes of the Asbestos case) asbestos products are unique, and that the French decree is a non-tariff barrier to their importation which is inconsistent with Article XI. As mentioned above, Canada instituted a claim that the French decree created a non-tariff barrier inconsistent with Article XI-a claim which was dealt with by neither the panel nor the Appellate Body. The panel found this claim extraneous to its findings that the French decree (1) was a violation of Article III:4, but (2) was justified under Article $\mathrm{XX}(\mathrm{b})$ as a measure necessary to protect human life or health. The Appellate Body (having overturned the panel's Article III:4 ruling) gave no explanation for not ruling on the Article XI claim. Even so, by upholding the panel with respect to Article XX(b), the Appellate Body, without giving any rationale for passing by the Article XI claim in silence, could have had an Article XX(b) rationale for doing so.

There are two problems with positing such a sub silencio rationale. The first is that it assumes, in the absence of panel findings, that Article XI forbids France from subjecting the importation of asbestos products from Canada to non-tariff "prohibitions or restrictions" of the type found in the French decree. A reading of the bare text of Article XI would appear to be consistent with this conclusion, but the Article XI claim was not critical to the approach adopted by the panel and therefore was not discussed by it. ${ }^{90}$

For present purposes, the second problem is more pertinent. Had the Appellate Body addressed the issue of whether the French decree was a violation of Article XI, the Appellate Body would not have been able to dispose of this issue on the ground that asbestos products and substitute products are not "like products." The entire "like products" analysis engaged in by the Appellate Body under Article III:4 would have been beside the point under Article XI. An Article XI violation, had one been found, would have sent the Appellate Body directly into Article XX(b) - the very

90. Article XI: 1 of GATT 1994 reads as follows: "No prohibitions or restrictions other than duties, taxes or other charges, whether made effective through quotas, import or export licenses or other measures, shall be instituted or maintained by any contracting party on the importation of any product of the territory of any other contracting party . ..." The panel did not consider this text, or the text of Ad Article III of GATT 1994, relied on by the EU (see supra text accompanying note 65 ). 
provision, of course, upon which the panel had ultimately rested its report.

\section{6. "Measures Necessary to Protect Human Life or Health"}

The French decree was concerned not with the three criteria of "likeness" relied on by the Appellate Body, but with the protection of human life and health. It was concerned not with the relative competitive aspects of toxicity viewed as a physical characteristic, not with evidence as to particular overlapping end-uses, and certainly not with consumer preferences. Quite irrespective of these factors, the French decree was adopted to protect human life and health by preventing a known carcinogen from being imported into or used in France.

The panel report, by moving rather efficiently into Article $\mathrm{XX}(\mathrm{b})$, was informed by the purpose of the French decree and, with an economy of effort, was drafted to evaluate the decree in terms of its manifest objective. Did the panel thereby fail to tarry any longer than it deemed absolutely necessary on the issue of "likeness"? Did it simply assume that there was at least some significant market for some asbestos products that were competitive with substitute products? These questions may slight the not inconsiderable attention given by the panel to the question of "likeness." Even so, it is tempting to think of the panel as looking upon the "likeness" debate as a somewhat arcane diversion from efficiently disposing of the French decree in terms of its stated objective and pursuant to that provision of GATT 1994 which expressly covers that objective.

The approach adopted by the panel raises two substantive legal issues, each of which is mentioned in the panel report. The first is whether the structure of GATT 1994 dictates the approach taken by the panel in dealing with a measure adopted to protect human life or health. The second is whether, in contrast to Article III:4, Article XX(b) places an undue burden of proof on the party to a trade dispute that is called upon to justify a trade barrier on the basis of the protection of human life or health.

\section{a. The Structure of GATT 1994}

It cannot be said that the panel's views are altogether lacking in merit. GATT 1994 follows the structure of the old GATT and brings with it over fifty years of jurisprudence. ${ }^{91}$ GATT 1994 is designed to remove barriers to trade and, at the same time, to recognize that there are legitimate purposes which constitute exceptions to that objective and which justify certain policy-oriented barriers to trade. In its general structure,

91. See Palmeter \& Mavroidis, supra note 2, at 1-18. 
GATT 1994 first creates violations of WTO law that arise when specified barriers to trade are erected, and then sets out exceptions to those violations, the exceptions being grounded in specifically recognized policies. ${ }^{92}$ Frequently, therefore, a case involving a trade dispute deals, first, with an alleged violation raised by the complaining party and, second, with a specific exception claimed by the defending party as a justification for the violation. For this reason, a defending party to a WTO trade dispute will frequently both deny an alleged violation and have recourse to one of the exceptions in order to justify the violation.

A highly relevant example is the 1996 report of the Appellate Body in a case involving clean-air environmental standards adopted by the United States for fuel additives (the "Gasoline Additives case"). ${ }^{93}$ Briefly, the United States had adopted stricter environmental standards for foreign gasoline refiners than for domestic gasoline refiners; Brazil and Venezuela had complained under Article III:4; and the United States had invoked one of the General Exceptions in Article XX-the exception "relating to the conservation of exhaustible natural resources" claimed natural resource being clean air. The panel had found a violation of Article III:4, and the United States had not appealed this finding. The issue before the Appellate Body, therefore, was whether the violation was justified under the claimed exception. The Appellate Body found that the U.S. measures in question were indeed "measures relating to the conservation of exhaustible natural resources." The Appellate Body then found, however, that the discriminatory feature of the U.S. measures, being stricter for foreign refiners than for domestic refiners, was inconsistent with the introductory clause of Article XX.

92. "General Exceptions" are found in GATT 1994 Article XX relating to (a) public morals, (b) human, animal or plant life or health, (c) trade in gold or silver, (d) securing compliance with domestic laws and regulations, (e) prison labor, (f) the protection of cultural treasures, $(\mathrm{g})$ conserving exhaustible natural resources, (h) obligations under commodity agreements, (i) assuring domestic access to essential materials, (j) dealing with products in short supply. "Security Exceptions" are found in Article XXI.

93. Report of the Appellate Body, United States-Standards for Reformulated and Conventional Gasoline, WT/DS2/AB/R (April 29, 1996), http://www.wto.org [hereinafter Gasoline Additives case].

94. GATT 1994 Art. XX(g).

95. The introductory clause (also known as the chapeau) reads:

Subject to the requirement that such measures are not applied in a manner which would constitute a means of arbitrary or unjustifiable discrimination between countries where the same conditions prevail, or a disguised restriction on international trade, nothing in this Agreement [GATT 1994] shall be construed to prevent the adoption or enforcement by any contracting party of [the following] measures.

GATT 1994 Art. XX chapeau. In the case of Article XX(b), the words following this clause are: "necessary to protect human, animal or plant life or health." 
The introductory clause of Article XX is designed to prevent trade protectionism in the guise of a measure that, ostensibly, serves an otherwise valid and recognized public policy, such as safeguarding the environment, or human life or health. Thus, to qualify as an exception under Article XX, a measure may not arbitrarily or unjustifiably discriminate "between countries where the same conditions prevail," and may not be "a disguised restriction on international trade." In the Gasoline Additives case, the Appellate Body found that the discriminatory feature of the U.S. regulations there at issue-which were stricter for foreign than for domestic refiners-rendered them an arbitrary and unjustifiable form of protectionism of domestic refiners as against foreign refiners, and a disguised restriction on international trade in refined gasoline. $^{96}$

The panel in the Asbestos case was quite cognizant of the implications of the Gasoline Additives case for dealing with the French decree under Article XX(b). The panel cited and referred to Gasoline Additives in scrupulous detail, and expressly couched its reasoning in terms of the conditions found in the introductory paragraph of Article XX as they apply to a measure claimed to be within the ambit of Article $\mathrm{XX}(\mathrm{b}){ }^{97}$ Moreover, the panel was urged by two countries that filed third-party briefs in the Asbestos case, Brazil and Zimbabwe, to take the position that the French decree was in effect an abuse of Article XX(b), and was more restrictive of international trade than was required in order to safeguard human life or health in France. ${ }^{98}$

Thus, by disposing of the Asbestos case under Article $\mathrm{XX}(\mathrm{b})$, the panel was dealing with a provision that required the EU (acting on behalf of France) to demonstrate that the French decree, first, was necessary for the protection of human life or health and, second, was not a trade-protectionist measure in the guise of a measure for the protection of human life or health. To meet the first requirement, the EU provided substantial evidence and testimony to establish the carcinogenic threat posed by asbestos products. ${ }^{99}$ To meet the second requirement, the EU could point to the text of the French decree itself, which applies its prohibitions equally to all asbestos products, domestic or foreign, and (in the language of the introductory paragraph of Article XX) does not arbitrarily or unjustifiably discriminate "between countries where the same

96. Gasoline Additives case, supra note 93, at 20-27 ("IV. The Introductory Provisions of Article XX of the General Agreement: Applying the Chapeau of the General Exceptions").

97. See Asbestos Panel report, supra note 3, पा| 8.227, 8.235-.237. These conditions were referred to as "le contrôle qu'exerce le paragraphe introductif de l'article XX sur les abus éventuels de l'article XX(b) dans l'application de la mesure." Id. 1 8.130.

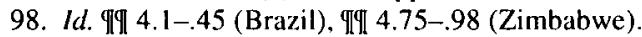

99. Id. III 5.574-.581. 
conditions prevail.,"100 Under the French decree, any country producing asbestos products faces the same prohibitions.

These two requirements imposed on the EU to justify the French decree pursuant to Article XX(b) have been seen by certain commentators as unduly burdensome. Thus, when the Appellate Body reversed the panel on the matter of "like products" under Article III:4, these commentators were of the view that the WTO had made it less burdensome to justify measures for the protection of human life or health-and, by extension, measures for the protection of the environment-and had thereby moved in a welcome and salutary direction. The comments were to the effect that a country defending such measures before the WTO would have an easier task, in terms of burden of proof, in showing that products were not "like products" under Article III:4 than in meeting the double requirement (just discussed) of Article XX(b). ${ }^{101}$

Possibly anticipating this line of reasoning, the panel had briefly observed that, for purposes of burden of proof, it made no significant difference whether the EU was required to show "unlikeness" under Article III:4, or was required to meet the requirements of Article $\mathrm{XX}(\mathrm{b}){ }^{102}$ In addition, according to the panel, because Article $\mathrm{XX}(\mathrm{b})$ is subject to the conditions found in the introductory paragraph of Article XX (described above), in applying Article $X X(b)$, the panel was following the principle laid down by the Appellate Body in earlier cases to give effect to all provisions ("donner sens à toutes les dispositions") of GATT 1994. ${ }^{103}$ Even so, the Appellate Body reversed the panel. The questions thus arise, was the panel correct as to burden of proof, or was the Appellate Body correct in reversing the panel on the issue of "likeness"?

\section{b. Burden of Proof}

Under WTO case law, the party bringing a complaint has the burden of bringing forth evidence to make out a prima facie case substantiating the complaint. Once the complaining party has made out such a case, the burden then shifts to the defending party to bring forth evidence to the contrary. It is for the panel hearing the case to decide when the burden shifts. This decision is subject to appeal to the Appellate Body. There is no WTO case law as to which party bears the ultimate burden of persuasion, a matter that is left to the several panels on a case-by-case basis and that is also subject to appeal. ${ }^{104}$

100. See id. .ाI 8.223-.224.

101. See NGO Commentaries, supra note 11.

102. Asbestos Panel report, supra note 3, II 8.130.

103. Id.

104. These statements as to WTO case law are based on the Report of the Appellate Body, United States-Measures Affecting Imports of Woven Wool Shirts and Blouses from 
In the Asbestos case, in respect of Canada's claim that asbestos products and substitute products are "like products" within the meaning of Article III:4, Canada had the burden of producing evidence making out a prima facie case to that effect, and, in the event Canada met that burden, the EU (on behalf of France) had the burden of producing contrary evidence to establish that the two categories of products are not "like products." The panel, looking basically at that moment when the two categories of products are put to the same end use, determined that Canada had made out a case for "likeness" and the EU had not made out a case for "unlikeness."

The Appellate Body did not agree with the criterion used by the panel in judging "likeness" versus "unlikeness," and effectively changed that criterion. According to the Appellate Body, each of the four criteria (only three of which were in fact invoked) from the Alcoholic Beverages case should be examined separately, and in the course of this examination toxicity should be considered a physical property for the purpose of weighing the relative competitiveness of the two categories of products. The Appellate Body thus reversed the panel not on the issue of burden of proof, but on the issue of the proper criterion for judging the type of proof required.

The panel had required proof in the context of one criterion. The Appellate Body ruled that the panel had should have required proof in a materially different context. Accordingly, the question of burden of proof was not addressed by the panel within the framework deemed applicable by the Appellate Body. Unable to send the case back to the panel, ${ }^{105}$ the Appellate Body purported to "complete the analysis" undertaken by the panel. At this point, the issue of burden of proof comes unraveled in the Asbestos case. The Appellate Body said two things: one, that toxicity should be considered when judging the competitiveness of the two categories of products; two, that when this factor is taken into account the complaining party (Canada) failed to adduce sufficient evidence as to "likeness." The issue of burden of proof thereupon becomes unraveled because, of course, Canada was never given an opportunity to bring forth evidence under the standard established by the Appellate Body on appeal. There is, therefore, no way of knowing whether, when Canada was presenting its case to the panel, it would then have made out a prima facie case that, viewed in terms of relative competitiveness and taking into account the toxicity of asbestos products, they are, notwithstanding their toxicity, competitively "like" substitute products.

India, WT/DS33/AB/R and Corr. 1 (April 25 and May 27, 1997), at 11-15 (IV. "Burden of Proof").

105. See Palmeter \& Mavroidis, supra note 2, at 147-52. 
A reading of the French decree and of the record in the Asbestos case suggests that asbestos products, notwithstanding their toxicity, may well be competitive with substitute products. The Appellate Body's speculative comments on consumer tastes do little to dispel the inference that consumers, cognizant of the fact that chrysotile asbestos is a deadly carcinogen, will nonetheless use asbestos products for the very reason that they are competitive with substitute products. In short, it seems quite speculative to assume that, had Canada, before the panel, been asked to make out a prima facie case of "likeness" under the standard established by the Appellate Body on appeal, Canada would have failed to do so. In the event that Canada had succeeded in doing so, then the burden of showing "unlikeness" would have shifted to the EU.

Guesswork as to what might have happened is an unsatisfactory way of dealing with the issue of burden of proof. Even so, one can ask whether, in terms of burden of proof, the Appellate Body made a constructive contribution to WTO law by coming forward with its new basis for judging whether a complaining party has made out a prima facie case. It is far from clear that the Appellate Body did act constructively. In an area where the defending party seems to have a genuine concern with protecting human life and health, the defending party, instead of arguing directly to that concern, is placed by the Appellate Body in the position of having to refute the competitiveness of products notwithstanding their threat to human health. Competitiveness is not the issue. Making it the issue diverts the parties and the panel from the central question of protecting human life and health.

Indeed, the analysis provided by the Appellate Body could make it more difficult, not easier, to deal with measures taken to protect human life and health, or to protect the environment. These are not measures readily susceptible of being judged in terms of relative competitiveness under Article III:4. As the Asbestos panel pointed out, these are measures expressly covered (as to human health) in Article XX(b). The panel was thus able to suggest that going directly to Article $\mathrm{XX}(\mathrm{b})$ placed no greater burden of proof on the EU than it would have faced under Article III:4 in attempting to rebut a prima facie case as to "likeness."

There is, of course, a further element in Article XX (mentioned by the panel), which is its introductory clause as interpreted by the Appellate Body in the Gasoline Additives case. Under that clause, a measure that ostensibly is designed to protect (for example) human health or the environment may not arbitrarily or unjustifiably discriminate between "countries where the same conditions prevail," or constitute a "disguised restriction on international trade." There may be advocates of environmental or other causes who would like to revise this provision. On its 
face, however, it has the merit of holding human life, health, or environmental measures to a standard of genuineness and fairness, and of not permitting them to be used to mask trade protectionism. In any event, the provision was invoked and elaborated on by the Appellate Body in the Gasoline Additives case. Revising it would probably bring into play interests on both sides of the issue. For example, given the position taken by Brazil and Zimbabwe in the Asbestos case ${ }^{106}$ and the position taken by many developing nations with respect WTO law generally, ${ }^{107}$ it can be expected that, were an effort made to change this provision, its retention might attract considerable support.

Let us indulge, for a moment, in a hypothetical inspired by the Gasoline Additives case. France adopts a somewhat different decree relating to asbestos products. This decree permits the importation and sale of asbestos products that have an established history of controlled use, monitored by the French Ministry of Health. The French Parliament, however, under pressure from domestic interests, gives the Ministry a budget for monitoring only French-source asbestos products. The result is that imported products are denied any means of meeting the requirements as to controlled use, and are thereby excluded. Should the WTO, in the name of protecting human life and health, permit this protectionist measure to pass challenge? No answer to this question is likely to satisfy all of the interest groups affected by it, and consideration of the question might well result in a decision to retain the introductory paragraph of Article XX in its present form.

To return to the Asbestos case, the Appellate Body, by introducing the notion that toxicity is relevant to competitiveness in the context of judging "likeness" under Article III:4, did nothing to clarify questions involving burden of proof. If anything, they have been confused. The standard of proof to be deduced from the Appellate Body's report was not applied in a functional way; that is, it was not elaborated in the actual hearing of the case, by either the panel or the Appellate Body. Future panels will have to deal with this confusion, and will have to do so lacking significant guidance as to how their decisions will be viewed on appeal.

\section{The TBT Agreement}

As mentioned above, Canada's claim in the Asbestos case that the French decree violated the TBT Agreement (the WTO agreement on

106. See supra text accompanying note 98.

107. See, e.g., Jagdish Bhagwati, Break the Link Between Trade and Labour, Fin. Times (London), Aug. 29, 2001, at 13; Thomas L. Friedman, Foreign Affairs: Protesting for Whom?, N.Y. Times, Apr. 24, 2001, at A 19. 
technical barriers to trade) was rejected by the panel on the ground that the TBT Agreement did not cover the decree; the panel's views were in turn rejected by the Appellate Body, but it did not dispose of Canada's claim, which was left in limbo. Two loose ends remain for commentary in this connection: should the Appellate Body (1) have rejected the views of the panel and (2) having done so, have left the Canadian claim unresolved?

The panel reasoned that the operative part of the French decree was a complete ban on importing and using asbestos, and that a complete ban is not a technical barrier to trade within the meaning of the TBT Agreement. The Appellate Body observed that the complete ban in one section of the decree was subject to certain exceptions elsewhere in the decree, which transformed the decree, considered as a whole, into a technical barrier to trade covered by the TBT Agreement. The Appellate Body did not make it clear, however, why the exceptions served to work this transformation, particularly since, as regards the issues raised in the Asbestos case, none of the exceptions seems to have been relevant. ${ }^{108}$ One could defer to the Appellate Body's superior expertise as regards the TBT Agreement, except for the fact that the Appellate Body seemed reluctant really to come to grips with that agreement, and shied away from "completing the analysis" of the panel by disposing of the Canadian claim thereunder.

Such diffidence on the part of the Appellate Body stands in stark contrast to its willingness to engage in analysis-completion in a great many areas. Moreover, the task here, but for the fact (mentioned above) that there seems to be a pervasive lack of eagerness to interpret the TBT Agreement, would not seem that difficult. The TBT Agreement can be viewed as a logical continuation of GATT 1994, the former being expressly intended to further the objectives of the latter. Thus, much as the Appellate Body has elsewhere grounded analysis-completion on the finding of "a logical continuum," it might have proceeded (once it, unlike the panel, found the TBT Agreement applicable) to dispose of Canada's claim. ${ }^{109}$

108. This aspect of the French decree was examined at length by the panel, which so concluded. See its discussion, which precedes its conclusion, Asbestos Panel report, supra note 3 , 歫 $8.72-.73$.

109. The Appellate Body distinguished its "logical continuum" reasoning in Report of the Appellate Body, Canada-Certain Measures Concerning Periodicals, WT/DS31/AB/R (July 30, 1997), http://www.wto.org, on the ground that, there, the second sentence of Article III:2 was "closely related" to the first sentence. Appellate Body Asbestos report, supra note 4, 11 79. The TBT Agreement as it applies to asbestos products could also be said to be "closely related" to GATT 1994 Article XX(b). The term "necessary" in the latter involves the same thought as avoiding "unnecessary obstacles" in $\$ 2.2$ of the former; and the wording of the 
The Appellate Body had analyzed Article XX(b) at length and had affirmed the panel's rejection, under Article XX(b), of Canada's principal claim under GATT 1994. The Appellate Body had thus already laid the groundwork for rejecting, for substantially the same reason, Canada's claim under the TBT Agreement. As mentioned above, one of the recitals of the TBT Agreement tracks Article XX(b), including the language on measures necessary to protect human life or health. It therefore would not seem to have required a very demanding exercise in analysiscompletion for the Appellate Body to have extended its discussion of Article XX(b) and the principal Canadian claim under GATT 1994, to have caused that discussion to embrace the Canadian claim under the TBT Agreement, and on that basis to have dismissed that claim as well.

If the Appellate Body (overcoming a seeming institutional allergy to construing the TBT Agreement) had taken this step, it could have implicitly provided a further indication that the panel's basic views on the applicability of Article $\mathrm{XX}(\mathrm{b})$ were not altogether lacking in merit. That is, by indicating that the claim under the TBT Agreement could be properly disposed of under the aegis of Article $\mathrm{XX}(\mathrm{b})$ as carried over into the TBT Agreement, the Appellate Body would have built on the findings of the panel already endorsed by the Appellate Body with respect to Article $\mathrm{XX}(\mathrm{b})$, and would thereby have signaled that the basic issues of the Asbestos case taken as a whole should have been dealt with under Article XX(b) as found in GATT 1994 or as effectively incorporated in the TBT Agreement. ${ }^{110}$ So doing, the Appellate Body would have established a salutary bridge between its own report and that of the panel and would have added constructively to WTO jurisprudence serving as a guide to future panels.

\section{ConClusion}

The uneasy relationship between panels and the Appellate Body is in need of attention, and the Appellate Body is well-situated to provide that attention. The objective should be to improve the quality of WTO dispute settlement. More constructive use should be made of the reasoning and substantive content of panel reports. Less institutional time (fewer precious institutional resources) should be devoted to revision engaged in for purposes that do not advance the resolution of the case at hand or

introductory clause of Article XX and of the sixth recital of the TBT Agreement are substantially identical.

110. See Professor Robert L. Howse, Application for Leave to File a Written Brief in the Matter of European Communities-Asbestos 3 (Nov. 10, 2000) (commenting on the TBT Agreement and Article XX(b) of GATT 1994) (unpublished manuscript, on file with author). 
the development of a useful jurisprudential framework for future cases. "1 That is, cases should be viewed in a rigorously disciplined manner as embodying individual disputes in need of proper resolution and, where appropriate, as tools for building useful precedent for future cases. When critics of the WTO process are in the background of a case, their criticism should be viewed as an opportunity to defend the process not by distorting it but by using it for the production of well-reasoned reports of the highest quality, solidly grounded in the relevant WTO agreements.

The panel and Appellate Body reports in the Asbestos case can serve as constructive examples of how a more effective relationship might exist between panels and the Appellate Body. The Asbestos panel first met with the parties in June 1999, and it met with the parties and with scientific experts at various times thereafter. It issued a preliminary report in June and a final report in July 2000, which was distributed in September of that year. The report is 517 single-spaced pages long, to which is attached an addendum of over 200 pages. ${ }^{12}$ These data constitute at least some evidence that the work of the panel was serious and substantial. At a minimum, the panel not only disposed of the issues but also framed them for the Appellate Body and provided a detailed background against which to consider the points raised on appeal. In November and December 2000, the parties filed their submissions with the Appellate Body, which heard oral argument in January 2001 and issued its report (71 double-spaced pages) in March of that year.

At issue was a French decree designed to protect the public from a known carcinogen, chrysotile asbestos. The panel report reveals the panel's perception that the Canadian challenge to this decree should be resolved under Article XX(b) of GATT 1994, which expressly covers measures necessary to protect human life and health. The panel in fact proceeded to dispose of the case under Article XX(b), and ruled in favor of the defending party (the EU acting on behalf of France). While the panel heard a great many arguments and a great deal of expert testimony, and wrote up the results of these hearings in some detail in its report, its reasoning was economical and to the point: it asked whether the decree at issue met the requirements of Article $\mathrm{XX}(\mathrm{b})$, it concluded that it did, and it ruled in favor of the defending party.

This presented the Appellate Body with an opportunity to deal with the case in an even more economical fashion, inasmuch as the panel had already evaluated the testimony and laid the groundwork for an appellate

111. In this connection, see Harrowsmith, supra note 8, at 115 .

112. Over half of these pages were devoted to the risk posed by asbestos products to human life or health (see supra note 67), that is, to the central subject-matter being considered under Article XX(b). 
affirmation in the event that (as it turned out) the Appellate Body agreed with the panel that the French decree was justified (could be upheld) under Article XX(b). The Appellate Body permitted itself, however, to get caught up in a dispute over the "likeness" of asbestos products and substitute products under Article III:4. To some extent, the Article III:4 issue had to be disposed of, because the parties had re-raised it on appeal. In this posture, however, since the Appellate Body agreed with the panel as to Article XX(b), the re-raising of Article III:4 should have been viewed by the Appellate Body for what it was, that is, as nothing more than precautionary maneuvering by the EU (and by Canada in response to the EU), lest the Appellate Body reverse the panel with respect to Article $\mathrm{XX}(\mathrm{b})$. Once the Appellate Body had decided to affirm the panel with respect to Article $\mathrm{XX}(\mathrm{b})$, it was in a position to avoid entanglement in the argument over "likeness" and to state that, in view of the disposition of the case under Article $\mathrm{XX}(\mathrm{b})$, there was no need to reach the question of "likeness" under Article III:4.

It is unclear to what extent this "unlikeness" dispute under Article III:4 may have been the result of disagreements within the Appellate Body or the AB Division itself, and to what extent it may have been influenced by outside groups dissatisfied that, in their view, the panel had imposed an undue burden of proof on the EU in its defense of the French decree. As regards the latter possible influence, the Appellate Body in the Asbestos case established procedures for the submission of briefs to it by non-governmental organizations. In response, seventeen applications for leave to file written briefs were submitted, none of which was accepted by the Appellate Body. ${ }^{113}$

Of course, in taking on the "likeness" dispute, the Appellate Body could have been motivated by reasons relating to the larger picture of WTO jurisprudence. When so motivated, however, the Appellate Body would be well advised to hold itself to a simple test: is it turning out a decision which clarifies existing jurisprudence and will serve as a useful guide to future panels? In the Asbestos case, the Appellate Body did not rise to the standard implicit in that test. Two members of the AB Division suggested an analytical approach that was not clearly supported by the evidence in the panel report, and which might not be supported by the evidence were the matter to be retried in light of the Appellate Body's report. The third member of the $A B$ Division sought to extend the concept of "likeness" in a manner which, if adopted, could complicate the resolution of future cases.

The analysis suggested by two members of the AB Division is that carcinogenic properties render products with those properties (here, as-

113. See Appellate Body Asbestos report, supra note 4, ๆી 54-57. 
bestos products) less competitive than products without those properties (here, substitute products). The evidence in the case did not support this analysis, and it may be factually unsupportable. In the absence of positive law like the French decree, the marketplace may be quite receptive to carcinogenic products even when competitive non-carcinogenic products are available. The Appellate Body did little for the stature of WTO jurisprudence by engaging in dubious analysis in order to reverse the panel as to "likeness."

The conclusion suggested by the third member of the AB Division was to the effect that the comparative consequences for human life and health should be a criterion for judging the "likeness" of products under Article III:4. Noble as this thought may be, it is not good law. The concept of "like products" in Article III is not a catch-all for every policy distinction that might be advanced for the purpose of showing one category of product "unlike" another. Article III:1 sets out the economic purpose of Article III by stating that domestic measures "should not be applied so as to afford protection to domestic production." Ad Article III (2), taking Article III to its widest scope, refers to "a directly competitive or substitutable product." The prohibition, then, is not against products that are carcinogenic or otherwise harmful, but against measures that are trade-protectionist. When it comes to carcinogens, the relevant prohibition (as indicated by the panel and affirmed by the Appellate Body) is found in Article XX(b).

There may have been some reluctance on the part of the Appellate Body to rely solely on Article XX(b) in view of the protests of some health and environmental groups following the issuance of the panel report, and their professed concerns over the burden of proof borne by the EU (on behalf of France) in respect of Article XX(b). The burden was twofold: the EU had to show that the French decree was "necessary" to protect human life or health; and the EU had to show that it met the conditions found in the introductory clause of Article XX (forbidding arbitrary or unjustifiable discrimination, and disguised barriers to trade). These requirements are not inherently hostile to measures designed to protect human life or health. They are hostile, rather, to measures that, on the pretext of protecting human life or health, further a policy of trade protectionism. In this respect, Article $\mathrm{XX}(\mathrm{b})$ is of a piece with the true focus of Article III, namely, the prohibition of measures designed for trade-protectionist purposes.

The balance struck in Article XX(b) may not please everyone, although, properly understood (as it may not be by some advocates of non-trade policies), it may in fact please a very large number of constituencies. Changing or circumventing Article $\mathrm{XX}(\mathrm{b})$ is bound to 
displease certain constituencies, such as developing countries suspicious of measures advocated by industrialized countries to protect health, the environment, or labor standards. In any event, this debate is not one that can be resolved in the context of WTO dispute resolution, and it is to be hoped that the Appellate Body in the Asbestos case was not so illadvised as to think that it was making a contribution to this debate. Rather, it would have made a helpful contribution had it, in affirming the panel as to Article $\mathrm{XX}(\mathrm{b})$, offered an explanation of the reasons underlying and policies served by that provision.

The uneasy relationship between panels and the Appellate Body does not facilitate judicial economy within the WTO and adversely affects the quality of its work in resolving disputes. Panels should be brought more closely and effectively into the dispute-resolution process. The Appellate Body should provide leadership to this end by fostering a judicious use of resources within the WTO dispute-settlement apparatus, by minimizing unnecessary digressions from the economical disposition of cases, and by consciously developing a workable framework of decisions of utility to panels and itself in the future. 